\title{
Effect of Some Psychoactive Drugs Used as 'Legal Highs' on Brain Neurotransmitters
}

\author{
Krystyna Gołembiowska $^{1} \cdot$ Alexandra Jurczak $^{1} \cdot$ Katarzyna Kamińska $^{1}$ • \\ Karolina Noworyta-Sokołowska ${ }^{1} \cdot$ Anna Górska ${ }^{1}$
}

Received: 5 August 2015/Revised: 28 September 2015/Accepted: 13 October 2015/Published online: 26 October 2015

(C) The Author(s) 2015. This article is published with open access at Springerlink.com

\begin{abstract}
New psychoactive "designer drugs" are synthetic compounds developed to provide similar effects to illicit drugs of abuse, but not subjected to legal control. The rapidly changing legal status of novel psychoactive drugs triggers the development of new compounds, analogs of well-known amphetamine or mescaline. New designer drugs used as substitutes in ecstasy pills are the least investigated and can cause life-threatening effects on users. The aim of our research was to examine the effects of acute administration of 4-methoxyamphetamine (PMA, 5 and $10 \mathrm{mg} / \mathrm{kg}$ ), 4-methoxy- $N$-methylamphetamine (PMMA, 5 and $10 \mathrm{mg} / \mathrm{kg}$ ), and mephedrone (MEPH, 5, 10 and $20 \mathrm{mg} /$ $\mathrm{kg}$ ) on extracellular and tissue level of dopamine (DA), 5-hydroxytryptamine (5-HT) and their metabolites in rat brain, by microdialysis method in freely moving animals and HPLC. Similarly to 3,4-methylenedioxymethamphetamine (MDMA, 5 and $10 \mathrm{mg} / \mathrm{kg}$ ) PMA, PMMA and MEPH enhanced the release of DA and 5-HT in rat striatum, nucleus accumbens, and frontal cortex. DA tissue content was increased by MEPH and PMMA in striatum, by MEPH, PMA, and PMMA in nucleus accumbens, and by PMA in frontal cortex. Instead, cortical DA level was decreased by MEPH and PMMA. MEPH did not influence 5-HT tissue level in striatum and nucleus accumbens, but decreased its level in frontal cortex. PMMA increased 5-HT content in striatum, while PMA enhanced it in nucleus accumbens and frontal cortex. Observed changes in brain monoamines and their metabolites by new
\end{abstract}

Krystyna Gołembiowska

nfgolemb@cyf-kr.edu.pl

1 Department of Pharmacology, Institute of Pharmacology, Polish Academy of Sciences, 12 Smętna, 31-343 Kraków, Poland psychoactive drugs suggest that these drugs may be capable of development of dependence. Further experiments are needed to fully investigate the neurotoxic and abuse potential of those drugs.

Keywords Mephedrone - PMA - PMMA - MDMA - DA · 5-HT · Rat brain

\section{Introduction}

According to recent EMCDDA report, over the past 5 years, there has been an unprecedented increase in the number, type, and availability of new psychoactive substances in Europe, which replace their illegal counterparts and are easily obtainable on the Internet. Continuing this trend, during 2014, a total of 101 new substances were reported for the first time to the EU Early Warning System (EMCDA 2014). It is likely that the growth of the market in new psychoactive substances will continue to pose a range of challenges for public health and drug policy over the next few years, especially due to their unknown pharmacologic and neurotoxic effects.

4-Methoxyamphetamine (PMA) and 4-methoxy- $N$-methylamphetamine (PMMA) are methoxylated phenylethylamine derivatives first encountered on the illegal market in 1970s. Because of their similarity to 3,4-methylenedioxymethamphetamine (MDMA) and replacing it in "ecstasy" tablets, they are widespread among young people and consumed without any safe testing (Daws et al. 2000). They are toxic at lower doses than MDMA (Johansen et al. 2003; Lurie et al. 2012) and evoke a delayed effect after ingestion (Felgate et al. 1998), which can lead to an increased intake. Clinical symptoms specific to PMA and PMMA poisoning include life-threatening hyperthermia, tachycardia, rhabdomyolysis, breathing problems, 
and acute renal failure (Caldicott et al. 2003; Dal Cason 2001; Johansen et al. 2003). The effect evoked by PMA and PMMA is mediated by their interaction with either 5-HT transporter (SERT) or dopamine transporter (DAT) to release those neurotransmitters and inhibit their uptake from presynaptic sites (Callaghan et al. 2005; Daws et al. 2000). However, long-term effects of their action are poorly understood. Studies in rodents suggest that PMA and PMMA are capable of producing acute serotonergic as well as dopaminergic neurotoxicity, although they are less potent than MDMA, which produces dose-dependent selective degeneration of 5-HT terminals in just 7 days after administration (Battaglia et al. 1987; Gough et al. 2002; Gudelsky and Yamamoto 2003; Molliver et al. 1990; Steele et al. 1992).

Additionally, in drug discrimination studies, PMA and PMMA show similarity to MDMA, which suggests their addictive potential (Dukat et al. 2002; Glennon et al. 1997, 2007; Young et al. 1999). These studies raise concern over the illicit use of amphetamine derivatives in combination as "UFO pills." Recently, the effect of acute doses of PMA and PMMA was investigated and has been proved to cause a release of DA and 5-HT in rat striatum and hippocampus (Matsumoto et al. 2014). A study by Callaghan and coworkers showed that repeated administration of PMA resulted in reductions in hippocampal SERT binding, synaptosomal 5-HT uptake, as well as 5-HIAA content in the cortex, but it remained without effect on 5-HT content (Callaghan et al. 2006). These data suggest that PMA has severe long-term implications for altering the 5-HT neurotransmission, but degeneration of serotonergic fibers is not clear.

Mephedrone (MEPH, 4-methylmethcathinone) is a synthetic derivative of cathinone that can be extracted from the leaves of khat plant (Catha edulis). Structurally, it is a substituted phenethylamine, and as beta-keto-analog of PMMA has powerful psychostimulant and entactogenic properties (Schifano et al. 2011). There is no much evidence on neurotoxicity of mephedrone; however, its psychomimetic effects are comparable to amphetamines since euphoria, elevated mood, and sexual stimulation were reported (Kehr et al. 2011). However, excessive intake leads to acute intoxication characterized by elevated heart rate, increased body temperature, chest pain, tremor, and convulsions (Wood and Dargan 2012; Zawilska 2014; Zawilska and Wojcieszak 2013). What is more, mephedrone has comparable abuse potential to cocaine or ecstasy, triggering repetitive and uncontrolled drug intake (McElrath and O'Neill 2011). There is limited information regarding pharmacodynamic mechanism of mephedrone action, although its profile of action is likely to be comparable with MDMA (Zawilska 2014; Zawilska and Wojcieszak 2013). Initial reports suggest that mephedrone interacts with plasma membrane monoamine transporters
(Baumann et al. 2012; Hadlock et al. 2011), blocks the neurotransmitter reuptake (Simmler et al. 2014), and stimulates their release to the synaptic cleft (Kehr et al. 2011). Recent studies in animal models have shown that repeated mephedrone injections in a pattern used to mimic psychostimulant "binge" treatment cause rapid decrease in striatal DA and hippocampal 5-HT transporter function, which suggests its neurotoxic nature (Martínez-Clemente et al. 2014). Mephedrone as well as amphetamine analogs' neurotoxicity could be mediated by increased cytosolic pool of both DA and 5-HT, which under conditions of vesicular transporter (VMAT2) blockade induce the generation of reactive oxygen species (ROS) as well as dihydroxybitryptamine toxic products, by means of neuronal monoamine metabolism (Colado et al. 2001; Sprague and Nichols 1995; Yamamoto et al. 1995; Wrona and Dryhurst 2001). Additionally, pharmacokinetic studies in rodents and humans have shown that mephedrone is metabolized in a similar pattern to ring-substituted amphetamines, suggesting that bioactive metabolites could be formed in vivo (Meyer et al. 2010).

The purpose of our study was to further complement, by use of in vivo microdialysis, the fundamental knowledge on the effects of selected psychostimulants on the central nervous system. We investigated the changes in DA and 5-HT release in striatum, nucleus accumbens septi, and frontal cortex, following single administration of PMA, PMMA, and MEPH, in the adult rat model. Additionally, we assayed the tissue content of monoamines and their metabolites after acute pretreatment with those psychostimulants. The effect of MDMA on DA and 5-HT release in various brain regions was also assessed for comparison.

\section{Materials and Methods}

\section{Animals}

The study was carried out on male Wistar-Han rats (Charles Rivers, Sulzfeld, Germany) weighing 280-300 g. The animals were housed in temperature- and humidity-controlled rooms under a 12-h light/12-h dark cycle, and had free access to standard laboratory food and tap water. The experiments were conducted in accordance with the European Union guidelines regarding the care and use of laboratory animals (Council Directive 86/609/EEC of November 24, 1986) and were approved by the II Local Bioethics Commission (Institute of Pharmacology, PAS, Kraków, Poland).

\section{Drugs and Reagents}

3,4-Methylenedioxymethamphetamine (MDMA), 4-methoxyamphetamine (PMA), and 4-methoxy- $N$-methylamphetamine 
Fig. 1 Chemical structure of drugs used in this study<smiles>COc1ccc(CC(C)N)cc1</smiles>

4-methoxyamphetamine (PMA)<smiles>CNC(C)C(=O)c1ccc(C)cc1</smiles>

4-methylmethcathinone (Mephedrone)<smiles>CNC(C)Cc1ccc(OC)cc1</smiles>

4-methoxymethamphetamine (PMMA)<smiles>CNC(C)Cc1ccc2c(c1)OCO2</smiles>

3,4-methylenedioxymethamphetamine (MDMA)
(PMMA) were purchased from Toronto Research Chemicals Inc. (Canada). ( \pm )-4-Methylmethcathinone (mephedrone) was purchased from Chemwatch (Australia). The chemicals used for HPLC were obtained from Merck (Warsaw, Poland), while ketamine hydrochloride and xylazine hydrochloride were purchased from Biowet (Puławy, Poland). Chemical structure of drugs is shown in Fig. 1.

\section{Brain Microdialysis}

Animals were anesthetized with ketamine $(75 \mathrm{mg} / \mathrm{kg})$ and xylazine $(10 \mathrm{mg} / \mathrm{kg})$, and vertical microdialysis probes were implanted into the striatum, nucleus accumbens, and frontal cortex, respectively, using the following coordinates: $\mathrm{AP}+1.8, \mathrm{~L}+3.0, \mathrm{~V}-7.0 ; \mathrm{AP}+1.6, \mathrm{~L}+1.1, \mathrm{~V}$ -8.0; $\mathrm{AP}+2.8, \mathrm{~L}+0.8, \mathrm{~V}-6.0$ from the dura (Paxinos and Watson 1999). On the next day, probe inlets were connected to a syringe pump (BAS, IN, USA) which delivered artificial spinal fluid (aCSF) composed of $[\mathrm{mM}]$ : $\mathrm{NaCl} 147, \mathrm{KCl} 2.7, \mathrm{MgCl}_{2} 1.0, \mathrm{CaCl}_{2} 1.2 ; \mathrm{pH} 7.4$ at a flow rate of $2 \mu \mathrm{l} / \mathrm{min}$. After $2 \mathrm{~h}$ of the washout period, three basal dialysate samples were collected every $20 \mathrm{~min}$; then animals were injected intraperitoneally with appropriate drugs in doses indicated in figure captions and fraction collection continued for $180 \mathrm{~min}$. At the end of the experiment, the rats were sacrificed and their brains were histologically examined to validate the probe placement.

\section{Analytical Procedure}

DA, 5-HT, 3,4-dihydroxyphenylacetic acid (DOPAC), homovanillic acid (HVA), and 5-hydroxyindoleacetic acid (5-HIAA) were analyzed by high-performance liquid chromatography (HPLC) with coulochemical detection. Chromatography was performed using an Ultimate 3000 System (Dionex, USA), coulochemical detector Coulochem III (model 5300, ESA, USA) with 5020 guard cell, 5014B microdialysis cell, and Hypersil Gold C18 analytical column $(3 \mu \mathrm{m}, 3 \times 100 \mathrm{~mm})$. The mobile phase was composed of $0.1 \mathrm{M}$ potassium phosphate buffer adjusted to pH 3.6, $0.5 \mathrm{mM} \mathrm{Na}$ EDTA, $16 \mathrm{mg} / \mathrm{L}$ 1-octanesulfonic acid sodium salt, and $2 \%$ methanol. The flow rate during analysis was set at $0.7 \mathrm{ml} / \mathrm{min}$. The applied potential of a guard cell was $600 \mathrm{mV}$, while those of microdialysis cells were $E 1=-50 \mathrm{mV}$ and $E 2=300 \mathrm{mV}$ with a sensitivity set at $50 \mathrm{nA} / \mathrm{V}$. The chromatographic data were processed by Chromeleon v. 6.80 (Dionex, USA) software run on a PC computer.

\section{The Tissue Content of DA, 5-HT, and Their Metabolites}

Animals were sacrificed by decapitation $3 \mathrm{~h}$ after intraperitoneal drugs administration. Brains were separated and several brain regions (striatum, nucleus accumbens septi, frontal cortex) were dissected in anatomical borders. The tissue levels of DA, 5-HT, DOPAC, HVA, and 5-HIAA were measured using a high-performance liquid chromatography (HPLC) with electrochemical detection. Briefly, tissue samples of brain structures were homogenized in ice-cold $0.1 \mathrm{M} \mathrm{HClO}_{4}$ and were centrifuged at $10,000 \mathrm{~g}$ for $10 \mathrm{~min}$ at $4{ }^{\circ} \mathrm{C}$. The supernatant $(3-5 \mu \mathrm{L})$ was injected into the HPLC system. The chromatography system consisted of an LC-4C amperometric detector with a cross-flow detector cell (BAS, IN, USA), a Ultimate 3000 pump (Thermo Scientific, USA), and a Hypersil Gold analytical column $(3 \mu \mathrm{m}, 100 \times 3 \mathrm{~mm}$, Thermo Scientific, 


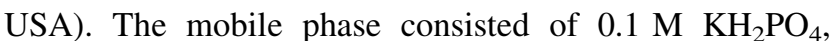
$0.5 \mathrm{mM} \mathrm{Na}{ }_{2}$ EDTA, $80 \mathrm{mg} / \mathrm{L}$ sodium 1-octanesulfonate, and a $4 \%$ methanol, adjusted to $\mathrm{pH} 3.7$ with an $85 \%$ $\mathrm{H}_{3} \mathrm{PO}_{4}$. The flow rate was $1 \mathrm{~mL} / \mathrm{min}$. The potential of a 3-mm glassy carbon electrode was set at $0.7 \mathrm{~V}$ with sensitivity of $5 \mathrm{nA} / \mathrm{V}$. The temperature of the column was maintained at $30{ }^{\circ} \mathrm{C}$. The Chromax 2007 program (PolLab, Warszawa, Poland) was used for data collection and analysis.

\section{Data Analysis}

All obtained data were presented as a percent of the basal level assumed as $100 \%$. The statistical significance was calculated using a repeated measures ANOVA or where appropriate a one-way ANOVA, followed by Tukey's post hoc test. The results were considered statistically significant when $P<0.05$.

\section{Results}

\section{DA and 5-HT Release in the Rat Striatum, Nucleus Accumbens, and Frontal Cortex After Administration of PMA}

PMA in doses of 5 and $10 \mathrm{mg} / \mathrm{kg}$ significantly increased DA release by ca. 300, 550, and $300 \%$ of basal level at 40-80 min after administration in striatum, frontal cortex, and nucleus accumbens, respectively (Fig. 2). Repeated measures ANOVA of these data showed a statistically significant effect of treatment groups $\left[F_{2,11}=121, P=0\right.$ in striatum; $\quad F_{2,11}=342, \quad P=0$ in frontal cortex; $F_{2,11}=1329, P=0$ in nucleus accumbens], sampling period $\left[F_{8,88}=32, P=0\right.$ in striatum; $F_{8,88}=95, P=0$ in frontal cortex; $F_{8,88}=34, P=0$ in nucleus accumbens], and the interaction between treatment groups and sampling period $\left[F_{16,88}=13, P=0\right.$ in striatum; $F_{16,88}=28, P=0$ in frontal cortex; $F_{16,88}=16, P=0$ in nucleus accumbens].

5-HT release was increased by PMA at both doses $(5$ and $10 \mathrm{mg} / \mathrm{kg}$ ) in striatum, frontal cortex, and nucleus accumbens by ca. 2000, 4000, and $500 \%$ of basal level, respectively, at $40 \mathrm{~min}$ after administration (Fig. 3). Repeated measures ANOVA of these data showed a statistically significant effect of treatment groups $\left[F_{2,11}=577, P=0\right.$ in striatum; $F_{2,11}=235, P=0$ in frontal cortex; $F_{2,11}=1883, P=0$ in nucleus accumbens $]$, sampling period $\left[F_{8,88}=48, P=0\right.$ in striatum; $F_{8,88}=102, P=0$ in frontal cortex; $F_{8,88}=72, P=0$ in nucleus accumbens], and the interaction between treatment groups and sampling period $\left[F_{16,88}=25, P=0\right.$ in striatum; $F_{16,88}=31, P=0$ in frontal cortex; $F_{16,88}=61$, $P=0$ in nucleus accumbens].
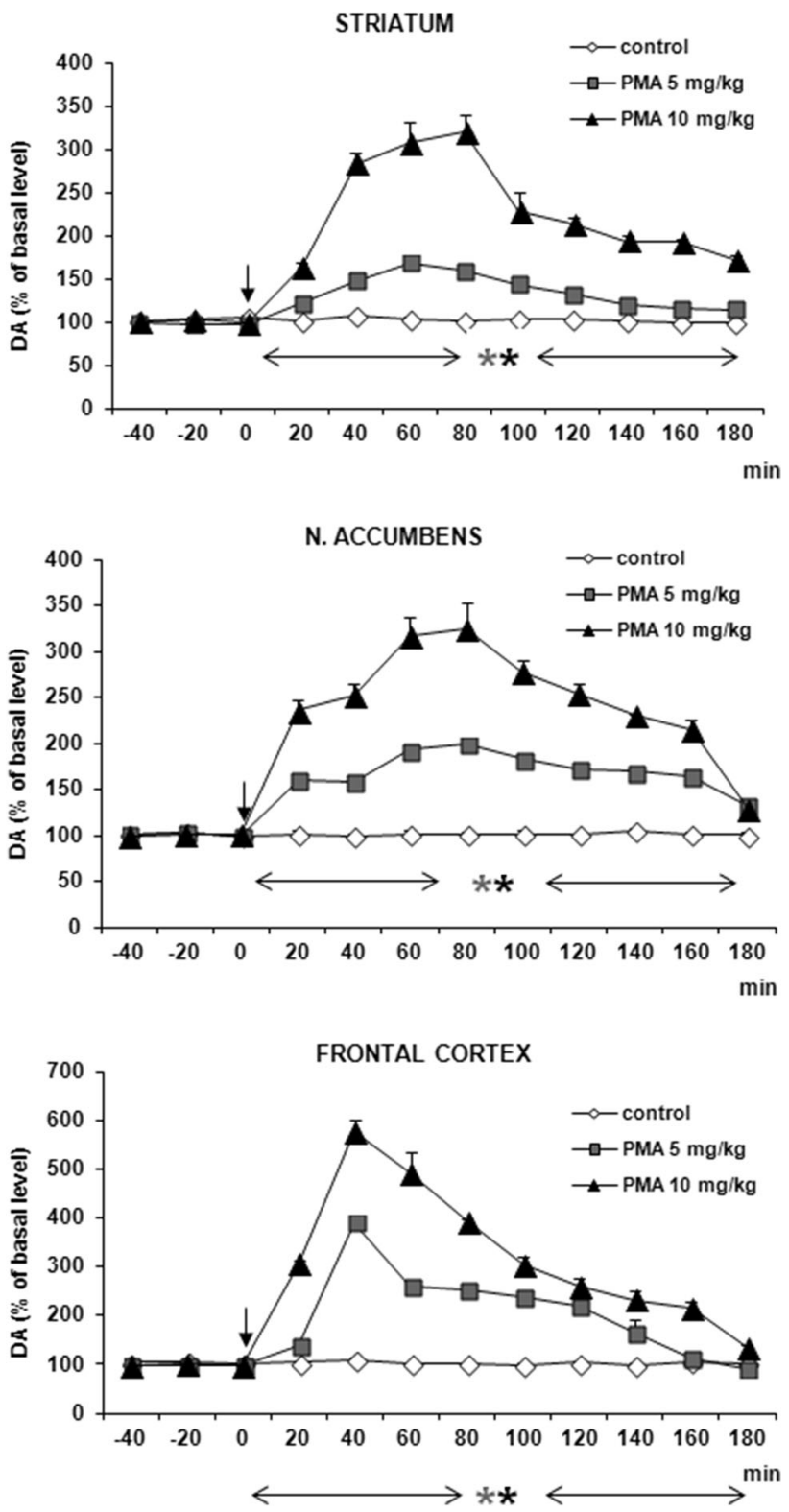

Fig. 2 Effect of PMA on DA release in rat striatum, nucleus accumbens, and frontal cortex. Data are mean \pm SEM $(n=4-5)$. Drug administration is indicated with an arrow. Basal extracellular level of DA (pg/10 $\mu \mathrm{l}$ ) was $18.9 \pm 0.8$ (striatum); $0.46 \pm 0.05$ (n. accumbens); and $1.20 \pm 0.14$ (frontal cortex). ${ }^{*} P<0.01$ in comparison to control group (repeated measures ANOVA and Tukey's post hoc test)

\section{DA and 5-HT Release in the Rat Striatum, Nucleus Accumbens, and Frontal Cortex After Administration of PMMA}

PMMA significantly increased DA release in both doses ( 5 and $10 \mathrm{mg} / \mathrm{kg}$ ) in frontal cortex and nucleus accumbens and at the higher dose in striatum only (Fig. 4). DA release was enhanced by ca. 300-400\% of basal level in all 

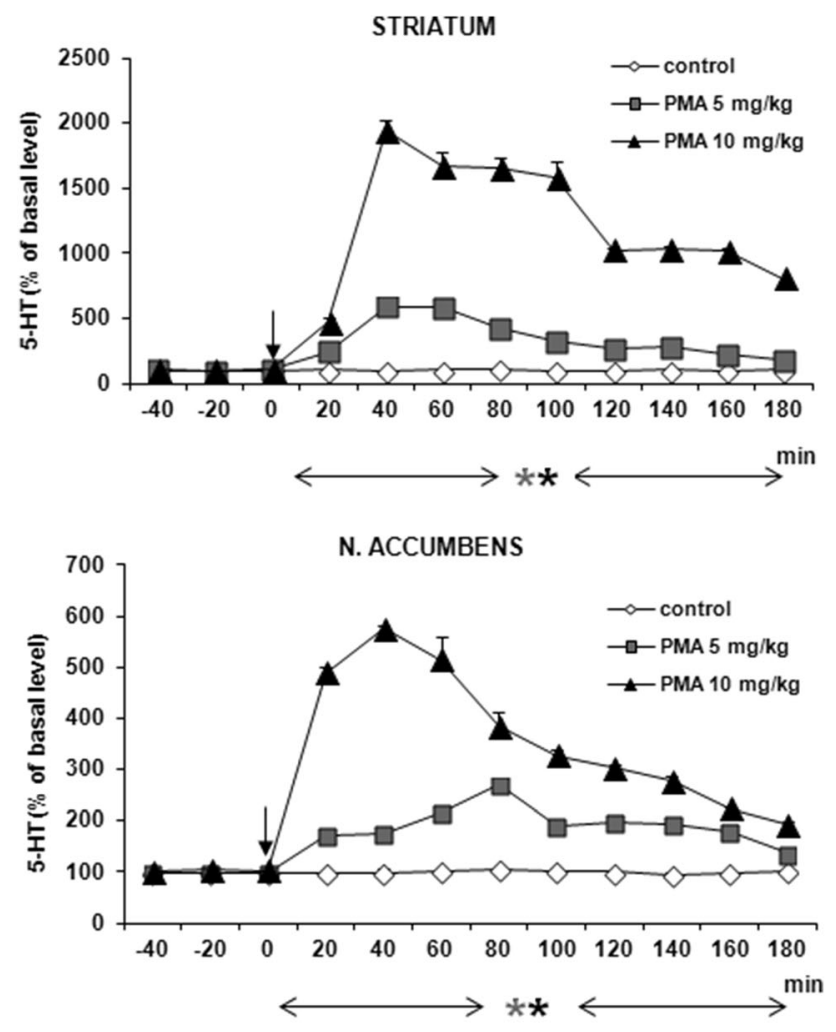

FRONTAL CORTEX

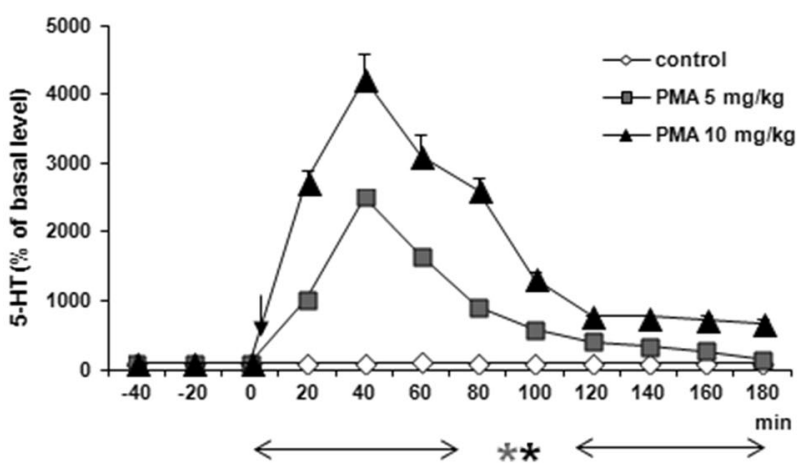

Fig. 3 Effect of PMA on 5-HT release in rat striatum, nucleus accumbens, and frontal cortex. Data are mean \pm SEM $(n=4-5)$. Drug administration is indicated with an arrow. Basal extracellular level of 5 -HT (pg/10 $\mu \mathrm{l}$ ) was $0.56 \pm 0.04$ (striatum); $0.14 \pm 0.02$ (n. accumbens); and $0.43 \pm 0.06$ (frontal cortex). $* P<0.01$ in comparison to control group (repeated measures ANOVA and Tukey's post hoc test)

studied brain regions at $60-80 \mathrm{~min}$ after administration. 5-HT release was increased by PMMA in both doses (5 and $10 \mathrm{mg} / \mathrm{kg}$ ) by ca. 700,1000 , and $400 \%$ of basal level at 40-100 min after administration in striatum, frontal cortex, and nucleus accumbens, respectively (Fig. 5). Repeated measures ANOVA of these data showed a statistically significant effect of treatment groups $\left[F_{2,11}=158, P=0\right.$ in striatum; $F_{2,11}=5092, P=0$ in frontal cortex;

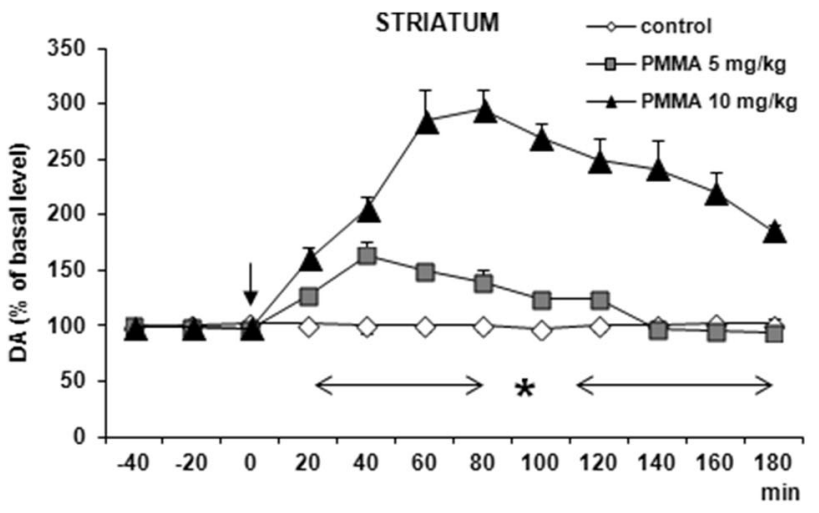

N. ACCUMBENS
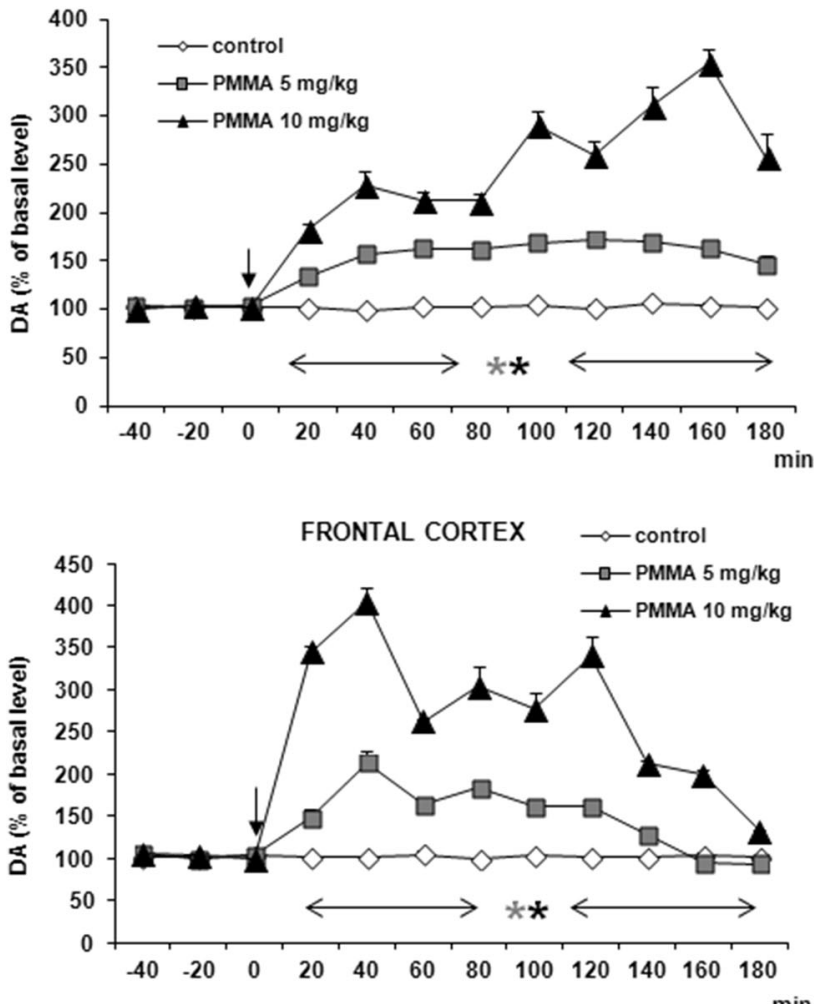

Fig. 4 Effect of PMMA on DA release in rat striatum, nucleus accumbens, and frontal cortex. Data are mean \pm SEM $(n=4-5)$. Drug administration is indicated with an arrow. Basal extracellular level of DA (pg/10 $\mu \mathrm{l}$ ) was $16.3 \pm 1.2$ (striatum); $0.81 \pm 0.07$ (n. accumbens); and $0.60 \pm 0.05$ (frontal cortex). ${ }^{*} P<0.01$ in comparison to control group (repeated measures ANOVA and Tukey's post hoc test)

$F_{2,11}=393, P=0$ in nucleus accumbens], sampling per$\operatorname{iod}\left[F_{8,88}=190, P=0\right.$ in striatum; $F_{8,88}=691, P=0$ in frontal cortex; $F_{8,88}=48, P=0$ in nucleus accumbens], and the interaction between treatment groups and sampling period $\left[F_{16,88}=60, P=0\right.$ in striatum; $F_{16,88}=255$, $P=0$ in frontal cortex; $F_{16,88}=23, P=0$ in nucleus accumbens]. 

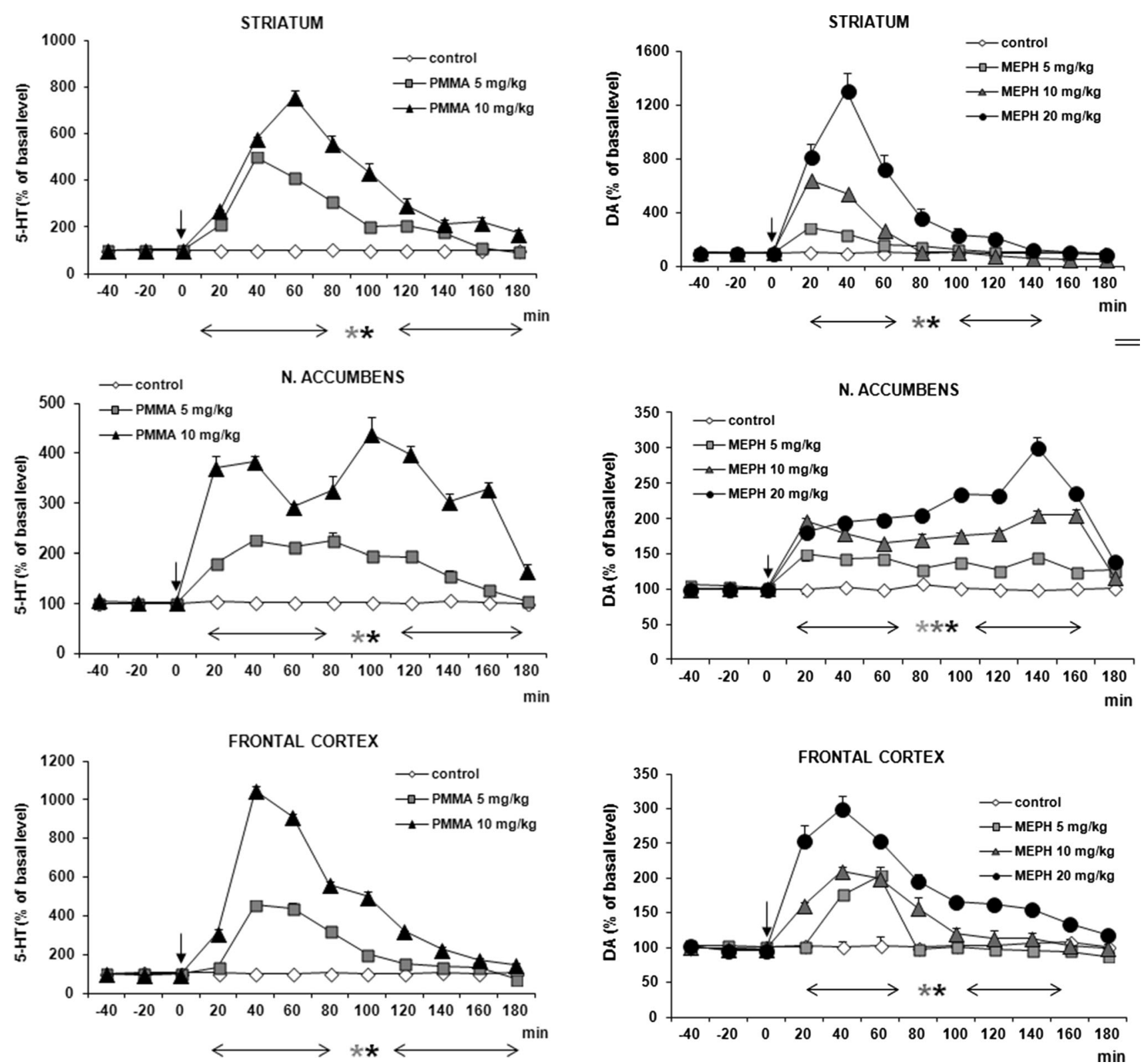

Fig. 5 Effect of PMMA on 5-HT release in rat striatum, nucleus accumbens and frontal cortex. Data are mean \pm SEM $(n=4-5)$. Drug administration is indicated with an arrow. Basal extracellular level of 5-HT ( $\mathrm{pg} / 10 \mu \mathrm{l})$ was $0.40 \pm 0.9$ (striatum); $0.22 \pm 0.03$ (n. accumbens); and $0.25 \pm 0.04$ (frontal cortex). $* P<0.01$ in comparison to control group (repeated measures ANOVA and Tukey's post hoc test)

\section{DA and 5-HT Release in the Rat Striatum, Nucleus Accumbens, and Frontal Cortex After Administration of Mephedrone}

Mephedrone at doses of 10 and $20 \mathrm{mg} / \mathrm{kg}$ significantly increased DA release in rat striatum and frontal cortex with maximum ca. 1200 and $300 \%$ of basal level, respectively, between 20 and 40 min after administration (Fig. 6). In

Fig. 6 Effect of mephedrone (MEPH) on DA release in rat striatum, nucleus accumbens, and frontal cortex. Data are mean \pm SEM $(n=4-5)$. Drug administration is indicated with an arrow. Basal extracellular level of DA $(\mathrm{pg} / 10 \mu \mathrm{l})$ was $18.7 \pm 1.6$ (striatum); $0.67 \pm 0.07$ (n. accumbens); and $0.57 \pm 0.06$ (frontal cortex). $* P<0.01$ in comparison to control group (repeated measures ANOVA and Tukey's post hoc test)

nucleus accumbens, doses of 5,10 , and $20 \mathrm{mg} / \mathrm{kg}$ significantly increased the DA release to maximum $250 \%$ of basal level at the highest dose (Fig. 6). Repeated measures ANOVA of these data showed a statistically significant effect of treatment groups $\left[F_{3,14}=76, P=0\right.$ in striatum; $F_{3,14}=158, P=0$ in frontal cortex; $F_{3,12}=1601, P=0$ in nucleus accumbens], sampling period $\left[F_{8,112}=94\right.$, $P=0$ in striatum; $F_{8,112}=86, P=0$ in frontal cortex; 

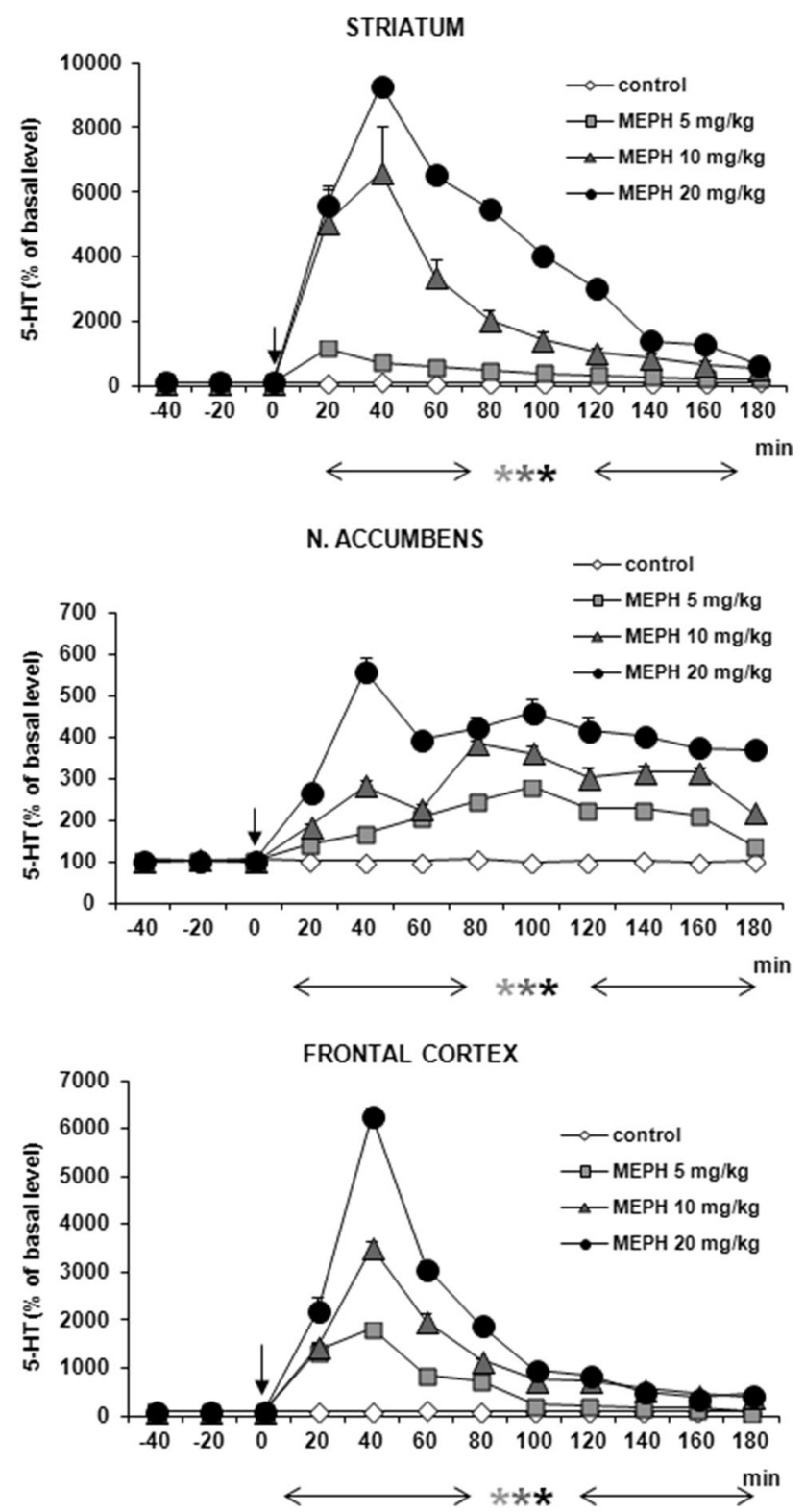

Fig. 7 Effect of mephedrone (MEPH) on 5-HT release in rat striatum, nucleus accumbens, and frontal cortex. Data are mean \pm SEM $(n=4-5)$. Drug administration is indicated with an arrow. Basal extracellular level of 5-HT $(\mathrm{pg} / 10 \mu \mathrm{l})$ was $0.24 \pm 0.05$ (striatum); $0.12 \pm 0.01$ (n. accumbens); and $0.14 \pm 0.01$ (frontal cortex). ${ }^{*} P<0.01$ in comparison to control group (repeated measures ANOVA and Tukey's post hoc test)

$F_{8,96}=96, P=0$ in nucleus accumbens], and the interaction between treatment groups and sampling period $\left[F_{24,112}=30, P=0\right.$ in striatum; $F_{24,112}=16, P=0$ in frontal cortex; $F_{24,96}=44, P=0$ in nucleus accumbens].

The effect of mephedrone on 5-HT release was more potent than on DA release. Mephedrone in all doses $(5,10$, and $20 \mathrm{mg} / \mathrm{kg}$ ) significantly increased 5 -HT release by ca. $500 \%$ of basal level in nucleus accumbens, while at doses of 10 and $20 \mathrm{mg} / \mathrm{kg}$ by ca. 8000 and $6000 \%$ of basal level
STRIATUM
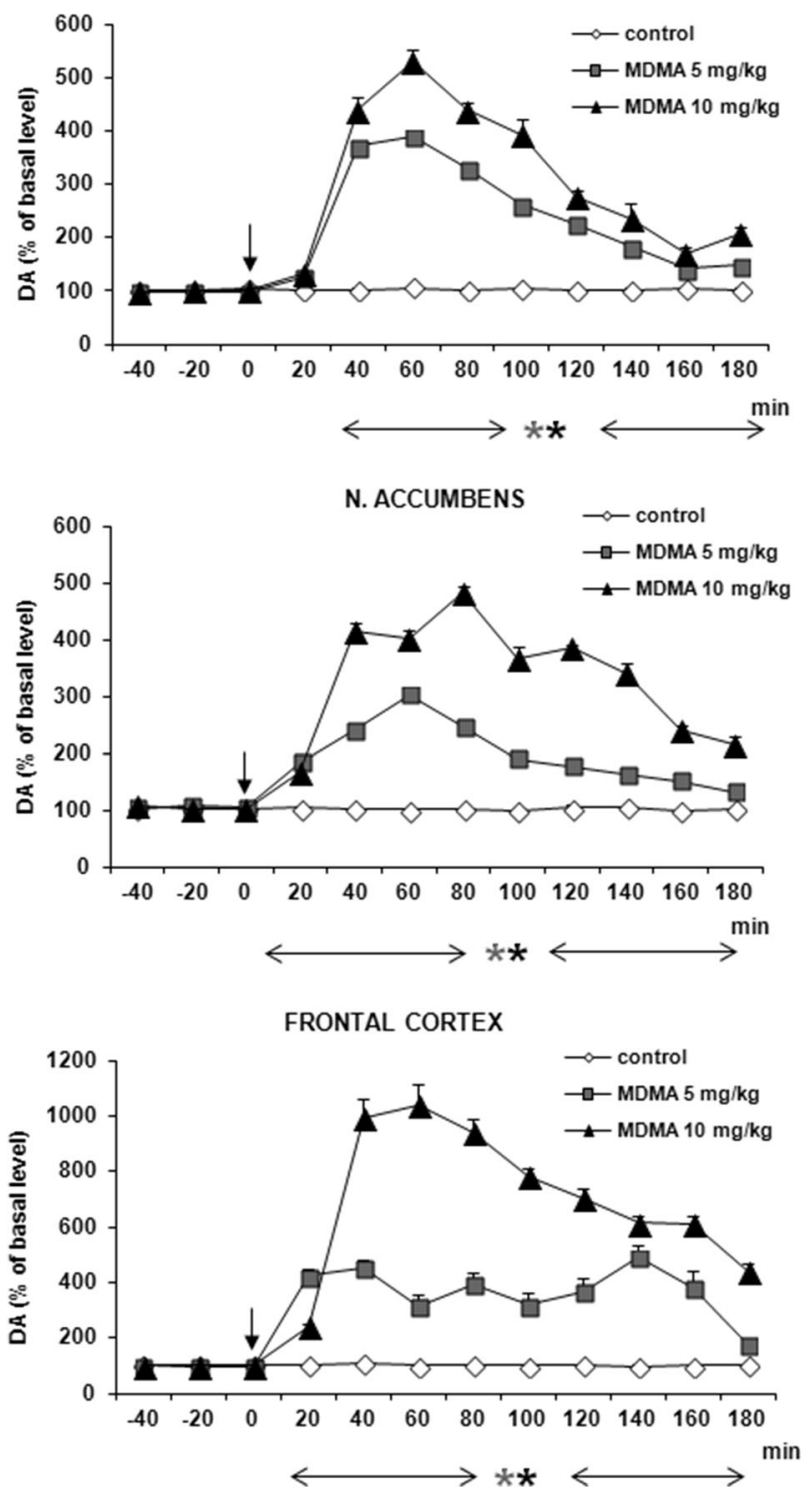

Fig. 8 Effect of MDMA on DA release in rat striatum, nucleus accumbens, and frontal cortex. Data are mean \pm SEM $(n=4-5)$. Drug administration is indicated with an arrow. Basal extracellular level of DA (pg/10 $\mu \mathrm{l}$ ) was $18.7 \pm 1.0$ (striatum); $1.01 \pm 0.14$ (n. accumbens); and $1.02 \pm 0.24$ (frontal cortex). ${ }^{*} P<0.01$ in comparison to control group (repeated measures ANOVA and Tukey's post hoc test)

in striatum and frontal cortex (Fig. 7). Repeated measures ANOVA of these data showed a statistically significant effect of treatment groups $\left[F_{3,14}=403, P=0\right.$ in striatum; $F_{3,14}=857, P=0$ in frontal cortex; $F_{3,12}=2056, P=0$ in nucleus accumbens], sampling period $\left[F_{8,112}=472\right.$, $P=0$ in striatum; $F_{8,112}=446, P=0$ in frontal cortex; $F_{8,96}=67, P=0$ in nucleus accumbens], and the interaction between treatment groups and sampling period $\left[F_{24,112}=154, P=0\right.$ in striatum; $F_{24,112}=99, P=0$ in frontal cortex; $F_{24,96}=22, P=0$ in nucleus accumbens]. 
DA and 5-HT Release in the Rat Striatum, Nucleus Accumbens, and Frontal Cortex After Administration of MDMA

MDMA at doses of 5 and $10 \mathrm{mg} / \mathrm{kg}$ significantly increased DA release by ca. 500, 400, and $1000 \%$ of basal level at 60-80 min after administration in striatum, nucleus accumbens and frontal cortex, respectively
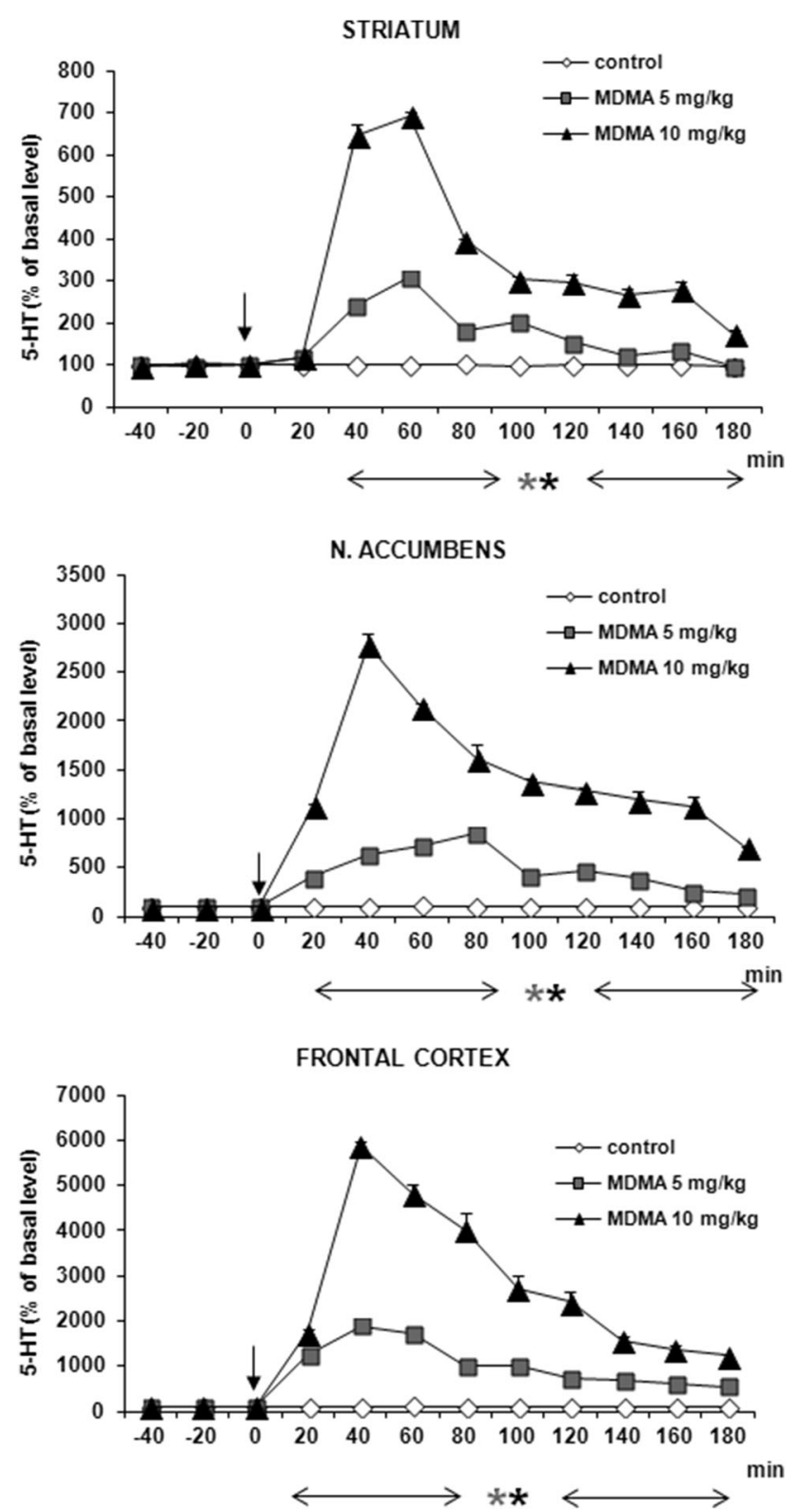

Fig. 9 Effect of MDMA on 5-HT release in rat striatum, nucleus accumbens, and frontal cortex. Data are mean \pm SEM $(n=4-5)$. Drug administration is indicated with an arrow. Basal extracellular level of 5-HT (pg/10 $\mu \mathrm{l}$ ) was $0.51 \pm 0.14$ (striatum); $0.19 \pm 0.04$ (n. accumbens); and $0.22 \pm 0.03$ (frontal cortex). $* P<0.01$ in comparison to control group (repeated measures ANOVA and Tukey's post hoc test)
(Fig. 8). Repeated measures ANOVA of these data showed a statistically significant effect of treatment groups $\left[F_{2,9}=193, P=0\right.$ in striatum; $F_{2,9}=1809$, $P=0$ in frontal cortex; $F_{2,9}=600, P=0$ in nucleus accumbens], sampling period $\left[F_{8,72}=169, P=0\right.$ in striatum; $\quad F_{8,72}=46, \quad P=0$ in frontal cortex; $F_{8,72}=120, P=0$ in nucleus accumbens], and the interaction between treatment groups and sampling period $\left[F_{16,72}=48, P=0\right.$ in striatum; $F_{16,72}=49, P=0$ in frontal cortex; $F_{16,72}=56, P=0$ in nucleus accumbens].

The effect of MDMA on 5-HT release was comparable in its potency to the effect on DA release in striatum reaching $600 \%$ of basal level at $60 \mathrm{~min}$ after administration (Fig. 9). However, MDMA markedly increased 5-HT release by ca. 2500 and $6000 \%$ of basal level in nucleus accumbens and frontal cortex (Fig. 9). Repeated measures ANOVA of these data showed a statistically significant effect of treatment groups $\left[F_{2,9}=523, P=0\right.$ in striatum; $F_{2,9}=311, P=0$ in frontal cortex; $F_{2,9}=691, P=0$ in nucleus accumbens], sampling period $\left[F_{8,72}=303, P=0\right.$ in striatum; $F_{8,72}=193, P=0$ in frontal cortex; $F_{8,72}=131, P=0$ in nucleus accumbens], and the interaction between treatment groups and sampling period $\left[F_{16,72}=136, P=0\right.$ in striatum; $F_{16,72}=101, P=0$ in frontal cortex; $F_{16,72}=71, P=0$ in nucleus accumbens].

Total Effect of PMA, PMMA, Mephedrone, and MDMA on DA and 5-HT Release in Brain Regions

The summarized time-course effect defined as an area under the curve (AUC) after administration of $10 \mathrm{mg} / \mathrm{kg}$ of each drug in all studied brain regions is provided in Table 1. PMA, PMMA, and mephedrone were nearly equally potent in increasing DA release in striatum. Mephedrone was slightly weaker in increasing DA release in nucleus accumbens and frontal cortex than PMA and PMMA, while MDMA remarkably increased DA release in all brain regions being the most potent in frontal cortex.

PMA and mephedrone markedly enhanced 5-HT release in striatum, but the increase induced by mephedrone was ca. twofold stronger than that by PMA. PMMA and MDMA produced weaker and nearly equal effect on 5-HT release in this brain region. PMA, PMMA, and mephedrone induced comparable increase in 5-HT release in nucleus accumbens and were nearly threefold weaker than MDMA. However, PMMA was weakest in increasing 5-HT release in frontal cortex, as PMA, mephedrone, and MDMA enhanced 5-HT release by ca. fourfold, two-and-ahalf-fold, and sixfold, respectively, when compared to PMMA (Table 1). 
Table 1 Total effect of PMA, PMMA, mephedrone (MEPH), and MDMA at a dose of $10 \mathrm{mg} /$ $\mathrm{kg}$ on DA and 5-HT release in the rat striatum, n. accumbens, and the frontal cortex

\begin{tabular}{lccc}
\hline Treatment $(\mathrm{mg} / \mathrm{kg})$ & \multicolumn{1}{c}{ Striatum } & N. accumbens & Frontal cortex \\
\hline DA (AUC \% of basal level) mean \pm SEM & & \\
Control & $903 \pm 11$ & $910 \pm 13$ & $924 \pm 13$ \\
PMA 10 & $2072 \pm 80^{*}$ & $2237 \pm 26^{*}$ & $2909 \pm 76^{*}$ \\
PMMA 10 & $2111 \pm 104^{*}$ & $2307 \pm 57^{*}$ & $2476 \pm 32^{*}$ \\
MEPH 10 & $1902 \pm 112^{*}$ & $1593 \pm 14^{*}$ & $1280 \pm 49^{*}$ \\
MDMA 10 & $2825 \pm 109^{*}$ & $3009 \pm 71^{*}$ & $6364 \pm 109^{*}$ \\
5-HT (AUC \% of basal level) mean \pm SEM & $897 \pm 16$ & & \\
Control & $11,170 \pm 291^{*}$ & $898 \pm 5$ & $922 \pm 7$ \\
PMA 10 & $3502 \pm 144^{*}$ & $3286 \pm 54^{*}$ & $16,962 \pm 740^{*}$ \\
PMMA 10 & $21,642 \pm 380^{*}$ & $2581 \pm 19^{*}$ & $4200 \pm 38^{*}$ \\
MEPH 10 & $3170 \pm 81^{*}$ & $13,370 \pm 419^{*}$ & $11,036 \pm 222^{*}$ \\
MDMA 10 & & $25,773 \pm 1231^{*}$
\end{tabular}

Values are mean $\pm \operatorname{SEM}(n=4)$ and express area under the curve (AUC) of the percent of basal level. * $P<0.001$ versus control group (one-way ANOVA and Tukey's post hoc test)
Table 2 Tissue content of DA, DOPAC, HVA, 5-HT, and 5-HIAA in rat striatum, nucleus accumbens, and frontal cortex measured $3 \mathrm{~h}$ after administration of PMA, PMMA, and mephedrone (MEPH);
$* P<0.05$, ** $P<0.01$ versus control group (one-way ANOVA and Tukey's post hoc test)

\begin{tabular}{|c|c|c|c|c|c|}
\hline Treatment (mg/kg) & DA & DOPAC & HVA & $5-\mathrm{HT}$ & 5-HIAA \\
\hline \multicolumn{6}{|c|}{ Striatum pg/mg wt \pm SEM $(n)$} \\
\hline Control & $10,606 \pm 402(9)$ & $1188 \pm 51(9)$ & $771 \pm 37$ (9) & $698 \pm 49(7)$ & $706 \pm 50(9)$ \\
\hline PMA 5 & $11,705 \pm 459(5)$ & $1078 \pm 98(5)$ & $795 \pm 56(5)$ & $646 \pm 57(5)$ & $520 \pm 56(5)^{*}$ \\
\hline PMA 10 & $11,733 \pm 329(5)$ & $855 \pm 54(5)^{*}$ & $755 \pm 56(5)$ & $656 \pm 41(5)$ & $493 \pm 36(5)^{*}$ \\
\hline PMMA 5 & $11,734 \pm 281$ & $1062 \pm 28(4)$ & $811 \pm 60(4)$ & $846 \pm 75$ (4) & $608 \pm 23(4)$ \\
\hline PMMA 10 & $16,092 \pm 1846(6)^{* *}$ & $924 \pm 28(6)^{*}$ & $1300 \pm 130(6)^{* *}$ & $1162 \pm 121(6)^{*}$ & $493 \pm 19(6)^{*}$ \\
\hline MEPH 10 & $13,349 \pm 612(5)$ & $1249 \pm 58(5)$ & $1053 \pm 79(5)^{*}$ & $762 \pm 56(5)$ & $655 \pm 36(5)$ \\
\hline MEPH 20 & $20,422 \pm 1957(5)^{* *}$ & $1864 \pm 162(5)^{*}$ & $1485 \pm 109(5)^{* *}$ & $715 \pm 86(5)$ & $854 \pm 94(5)$ \\
\hline \multicolumn{6}{|c|}{ Nucleus accumbens pg/mg wt \pm SEM $(n)$} \\
\hline Control & $9992 \pm 341(12)$ & $1560 \pm 102(8)$ & $1137 \pm 104(10)$ & $912 \pm 64(11)$ & $759 \pm 54(12)$ \\
\hline PMA 5 & $12,608 \pm 1225(5) * *$ & $1447 \pm 124(5)$ & $1235 \pm 106(5)$ & $1326 \pm 71(5)^{*}$ & $935 \pm 89(5)$ \\
\hline PMA 10 & $18,117 \pm 988(5)^{* *}$ & $1860 \pm 145(5)$ & $1221 \pm 128(5)$ & $1685 \pm 212(5)^{* *}$ & $1285 \pm 84(5)^{* *}$ \\
\hline PMMA 5 & $13,668 \pm 781(5)^{* *}$ & $1560 \pm 95(4)$ & $1129 \pm 139(5)$ & $1139 \pm 142(4)$ & $515 \pm 74(4)^{*}$ \\
\hline PMMA 10 & $17,076 \pm 990(5)^{* *}$ & $1331 \pm 73(6)$ & $1027 \pm 94(5)$ & $1180 \pm 124(6)$ & $465 \pm 49(6)^{*}$ \\
\hline МЕPH 10 & $15,443 \pm 934(5)^{* *}$ & $2113 \pm 123(5)^{* *}$ & $1212 \pm 147(5)$ & $877 \pm 62(5)$ & $861 \pm 37(5)$ \\
\hline МЕPH 20 & $19,235 \pm 757(5)^{* *}$ & $2608 \pm 189(5)^{* *}$ & $1691 \pm 67(5)^{*}$ & $1045 \pm 136(5)$ & $763 \pm 54(5)$ \\
\hline \multicolumn{6}{|c|}{ Frontal cortex pg/mg wt \pm SEM $(n)$} \\
\hline Control & $1163 \pm 49(9)$ & $380 \pm 47(14)$ & $127 \pm 10(11)$ & $637 \pm 49(12)$ & $318 \pm 44(10)$ \\
\hline PMA 5 & $1247 \pm 81(5)$ & $193 \pm 21(5)^{* *}$ & $205 \pm 15(5)^{* *}$ & $1291 \pm 59(5)^{* *}$ & $567 \pm 46(5)^{*}$ \\
\hline PMA 10 & $1620 \pm 102(5)^{* *}$ & $131 \pm 8(5)^{* *}$ & $253 \pm 19(5)^{* *}$ & $1501 \pm 12(5)^{* *}$ & $870 \pm 42(5)^{* *}$ \\
\hline PMMA 5 & $849 \pm 31(4)^{*}$ & $285 \pm 54(4)$ & $150 \pm 16$ & $716 \pm 34$ & $226 \pm 21$ \\
\hline PMMA 10 & $638 \pm 49(6)^{* *}$ & $190 \pm 25(6)^{* *}$ & $294 \pm 46(6)^{* *}$ & $1205 \pm 71(6)^{* *}$ & $279 \pm 21(6)$ \\
\hline MEPH 10 & $526 \pm 64(5)^{* *}$ & $174 \pm 34(5)^{* *}$ & $85 \pm 1.5(5)^{*}$ & $423 \pm 46(5)^{*}$ & $291 \pm 81(5)$ \\
\hline MEPH 20 & $380 \pm 65(5)^{* *}$ & $86 \pm 5(5)^{* *}$ & $70 \pm 3.1(5)^{* *}$ & $332 \pm 7.8(5)^{* *}$ & $288 \pm 35(5)^{*}$ \\
\hline
\end{tabular}


The Tissue Content of DA, 5-HT, and Their Metabolites in the Rat Striatum, Nucleus Accumbens, and Frontal Cortex After Administration of PMA

PMA at doses 5 and $10 \mathrm{mg} / \mathrm{kg}$ significantly enhanced DA tissue content in nucleus accumbens $(P<0.01)$, at higher dose in frontal cortex $(P<0.01)$, and did not change its level in striatum (Table 2). The DOPAC tissue level was increased by both PMA doses in frontal cortex $(P<0.01)$, by higher dose in striatum $(P<0.05)$, and remained unchanged in nucleus accumbens (Table 2). PMA in both doses significantly enhanced HVA tissue level in frontal cortex $(P<0.01)$, while it did not change its level in striatum and nucleus accumbens (Table 2).

5-HT tissue level was potently increased by both doses of PMA in frontal cortex $(P<0.01)$ as it did in nucleus accumbens at doses of 5 and $10 \mathrm{mg} / \mathrm{kg}(P<0.05$ and $P<0.01$, respectively), but remained unchanged in striatum (Table 2). 5-HIAA content was decreased by both PMA doses in striatum $(P<0.05)$, but it was increased by PMA $(10 \mathrm{mg} / \mathrm{kg}, P<0.01)$ in nucleus accumbens and in frontal cortex by 5 and $10 \mathrm{mg} / \mathrm{kg}$ of PMA $(P<0.05$ and $P<0.01$, respectively).

\section{The Tissue Content of DA, 5-HT, and Their Metabolites in the Rat Striatum, Nucleus Accumbens, and Frontal Cortex After Administration of PMMA}

PMMA at a dose of $10 \mathrm{mg} / \mathrm{kg}$ significantly increased DA content in striatum $(P<0.01)$ and at both doses in nucleus accumbens $(P<0.01)$, but decreased its tissue level at doses of 5 and $10 \mathrm{mg} / \mathrm{kg} \quad(P<0.05$ and $P<0.01$, respectively) in frontal cortex (Table 2). Higher doses of PMMA significantly decreased DOPAC tissue level in striatum $(P<0.05)$ and in frontal cortex $(P<0.01)$ but did not change its level in nucleus accumbens (Table 2). HVA tissue level was increased by PMMA $(10 \mathrm{mg} / \mathrm{kg})$ in striatum and frontal cortex $(P<0.01)$ but remained unchanged in the nucleus accumbens (Table 2).

5-HT content was increased by PMMA at a dose of $10 \mathrm{mg} / \mathrm{kg}$ in striatum $(P<0.05)$ and in frontal cortex $(P<0.01)$, while it was not affected by PMMA in nucleus accumbens (Table 2). PMMA in both doses decreased 5-HIAA tissue level in nucleus accumbens $(P<0.05)$ and at a higher dose in the striatum $(P<0.05)$ but did not influence 5-HIAA content in frontal cortex (Table 2).
The Tissue Content of DA, 5-HT and Their Metabolites in the Rat Striatum, Nucleus Accumbens and Frontal Cortex After Administration of Mephedrone

Mephedrone studied in doses of 10 and $20 \mathrm{mg} / \mathrm{kg}$ enhanced DA content in frontal cortex $(P<0.01)$ and nucleus accumbens, while in striatum only at a higher dose (Table 2). Similarly, DOPAC level was significantly increased by both mephedrone doses in frontal cortex and nucleus accumbens $(P<0.01)$, while that in striatum by the higher dose only $(P<0.05)$. HVA tissue level was significantly increased in striatum and frontal cortex by 10 and $20 \mathrm{mg} / \mathrm{kg}$ of mephedrone $(P<0.05$ and $P<0.01$, respectively), while in nucleus accumbens, its level was enhanced by the higher dose only $(P<0.05)$.

5-HT and 5-HIAA tissue levels were not changed by mephedrone at both doses tested in striatum and nucleus accumbens (Table 2). In frontal cortex, mephedrone significantly decreased (at both doses) 5-HT tissue level $(P<0.01)$, while 5-HIAA level was significantly decreased by a higher dose only $(P<0.05)$.

\section{Discussion}

The main finding of our study is that although some differences in potency were observed, mephedrone, PMA, and PMMA markedly increased DA and 5-HT release in the rat striatum, the nucleus accumbens, and the frontal cortex and induced changes in the monoamine turnover in the rat brain.

In our study, single doses of PMA increased DA release in rat striatum and nucleus accumbens with similar potency but with a slightly greater effect in the frontal cortex. However, PMA effect on 5-HT was stronger than on DA release in all brain regions. These data are consistent with in vitro monoamine uptake inhibition profile of PMA since it was nearly 30 -fold less potent at the DAT versus SERT (Simmler et al. 2014). Our results are in line with study of Gough et al. (2002) who reported an increase in striatal DA and 5-HT in freely moving rats, but at much higher dose regimen $(10$ and $20 \mathrm{mg} / \mathrm{kg})$. The difference in potency of the drug may be due to rat strain or housing conditions, such as room temperature and single versus grouped housing, which strongly influence the effect of psychostimulant drugs (Green and Nutt 2014). Our results are also consistent with those of Matsumoto et al. (2014) who found remarkable increase in the level of 5-HT in rat hippocampus but lower increase in striatal DA level after PMA at a dose of $5 \mathrm{mg} / \mathrm{kg}$. Callaghan et al. (2005) suggest 
in chronoamperometric studies that the more prominent PMA effect on 5-HT level observed in rat striatum may be related with its clearance by both the SERT and DAT.

Increase in DA content in nucleus accumbens and frontal cortex, with concomitant decrease or no change in DOPAC or HVA content in those brain regions, seems to result from DAT inhibition and disturbed intracellular monoamine metabolism via MAO, caused by PMA (Matsumoto et al. 2014). Similarly, DAT transport inhibition seems to be responsible for the decrease in striatal DOPAC content caused by the high dose of PMA (Gough et al. 2002). Serotonin neurons in nucleus accumbens and frontal cortex are also markedly affected by PMA. Increase in 5-HT and its metabolite speaks for stimulatory effect of PMA on 5-HT synthesis. It is possible that PMA besides promoting 5-HT release may have direct impact on serotonin neurons via stimulation of 5-HT2A receptors (Simmler et al. 2014). This effect seems to be region specific as it is not observed in striatum where the decrease in 5-HT metabolism may result from SERT inhibition by PMA (Callaghan et al. 2005; Daws et al. 2000; Freezer et al. 2005).

PMMA, similarly to PMA, is a potent SERT but weak DAT inhibitor (Simmler et al. 2014). In our work, it increased DA and 5-HT release in all studied brain regions, but PMMA effect on 5-HT release in striatum and frontal cortex was not as strong as that of PMA; nevertheless, it was greater than on DA release in all tested regions. These data are in agreement with results reported by Matsumoto et al. (2014) who observed remarkable increase in hippocampal level of 5-HT by PMMA but a slight increase in levels of DA in striatum. Interestingly, in our study, the time-course effect of PMMA on DA release varied between brain regions. The maximal increase in DA level was at $80 \mathrm{~min}$ in striatum and $40 \mathrm{~min}$ in frontal cortex but was delayed in nucleus accumbens to $160 \mathrm{~min}$ after drug administration. Similar pattern as for DA was also observed in 5-HT release with similar effect in magnitude in striatum and frontal cortex and more extended time course in nucleus accumbens. It seems that increase in cortical DA or 5-HT level may account for the delay in accumbal DA release via GABA-ergic cortical projections to the nucleus accumbens (Lee et al. 2014). Moreover, formation of PMA as an active N-demethylated metabolite of PMMA may relate to delayed effect on DA and 5-HT release observed in the nucleus accumbens but not in other brain regions (Rohanova and Balikova 2009).

PMMA, similarly to PMA also enhanced DA content in striatum and nucleus accumbens. However, its influence on DOPAC and HVA level in both regions was not quite consistent. Similarly to mephedrone, PMMA decreased DA and DOPAC content in frontal cortex, which suggests regulation of DA cortical neurons by released 5-HT or directly by
PMMA via 5HT2A/2C receptors (Bankson and Yamamoto 2004; Di Giovanni et al. 2001; Di Matteo et al. 2001; Gudelsky and Yamamoto 2008). Increase in striatum and frontal cortex or lack of change in nucleus accumbens of 5-HT content with concomitant decrease or no change in 5-HIAA content seems to reflect the effect of PMMA on SERT inhibition, which may lead to malfunction of 5-HT metabolism.

Mephedrone, as a beta-keto-analog of amphetamines, is a nonselective substrate for plasma membrane monoamine transporters that also releases monoamines similarly to classic amphetamines (Baumann et al. 2012; Pifl et al. 2015; Simmler et al. 2014). In our study, mephedrone stimulated DA and 5-HT release in striatum, nucleus accumbens, and frontal cortex, with the magnitude of effect on 5-HT being greater. These findings are consistent with previous studies that report relatively stronger in vitro effect of mephedrone on 5-HT release than on DA release in HEK 293 cells and lower DAT: SERT ratio (Rickli et al. 2015). Our data resemble those of Kehr et al. (2011), who showed rapid and significant increase in 5-HT and DA levels in nucleus accumbens of awake rats after subcutaneous administration of 1 and $3 \mathrm{mg} / \mathrm{kg}$ of mephedrone. Similarly to our results, these researchers observed that mephedrone was a more preferential releaser of 5-HT than DA. In recent study of Shortall et al. (2015), three injections of mephedrone $(10 \mathrm{mg} / \mathrm{kg})$ in 2 -h intervals increased striatal release of DA and 5-HT following each injection. The magnitude of DA increase was similar to that shown in our work, but we observed a more potent increase in striatal 5-HT level after single administration of mephedrone. The difference in neuronal response to mephedrone in study of Shortall et al. (2015) and ours may be related with different rat strains used in both studies as well as technical details such as one drug injection versus three injections. The increase in DA release, which was short in duration in striatum or frontal cortex and a more prolonged in nucleus accumbens, corresponds with locomotor stimulation and self-administration reported by Motbey et al. (2014). What is more, those observed changes in DA release point out the addiction liability of mephedrone. As a consequence of predominant increase in 5-HT release and marked direct affinity to 5-HT2A receptor (Rickli et al. 2015) mephedrone may produce hallucinogenic effect (Nicholas 2004). By stimulation of DA release from mesolimbic and mesocortical dopamine terminals indirectly via DAT inhibition or directly via 5-HT2A receptors in the ventral tegmental area (VTA), mephedrone may evoke addiction and increase locomotor activity (Green et al. 2014; Iversen et al. 2014).

In our study, single doses of mephedrone caused marked increase in striatal and accumbal DA tissue content as well as its metabolites, DOPAC and HVA. This effect indicates an increase in DA synthesis mediated possibly postsynaptically via D1/D2 dopamine receptors situated in medium spiny GABA-ergic neurons or through 5-HT2A receptors activation 
(by released 5-HT), which are located on glutamatergic neurons, projecting from striatum or nucleus accumbens to nigral or VTA regions (Di Matteo et al. 2008). In contrast, mephedrone decreased the content of DA, DOPAC, and HVA in the frontal cortex. This indicates reductions in DA synthesis which may be mediated indirectly by released 5-HT. As mesolimbic and mesocortical neurons are highly regulated by inhibitory GABA-ergic neurons, their stimulation by released 5-HT via 5-HT2C receptors may inhibit VTA neurons and lead to a decrease in DA synthesis (Bankson and Yamamoto 2004; Di Giovanni et al. 2001; Di Matteo et al. 2001). Interestingly, while mephedrone did not affect serotonin turnover in striatum and nucleus accumbens, it decreased 5-HT and 5-HIAA contents in the frontal cortex, suggesting the possible acute damaging properties of mephedrone. This observation is interesting in terms of neurotoxicity of the drug, previously noted only after "binge" model of administration in rats and mice (Angoa-Pérez et al. 2013; Baumann et al. 2012; LópezArnau et al. 2015; Hadlock et al. 2011).

In comparison to PMA, PMMA, and mephedrone, MDMA (used here as a reference drug) produced a similar effect on DA release but markedly promoted the release of 5-HT in nucleus accumbens and frontal cortex. Similarly to the paramethoxyamphetamines and mephedrone, MDMA has a higher affinity for SERT than DAT and is more potent in releasing 5-HT than DA (Rothman and Baumann 2003). The effect of equal doses of PMMA, mephedrone, and MDMA on DA and 5-HT release presented in Table 1 indicates apparent differences between tested drugs. The amount of DA released in striatum was similar for PMA, PMMA, and mephedrone; however, mephedrone was less potent in nucleus accumbens and frontal cortex. The action of MDMA on DA release was more robust than PMA, PMMA, and mephedrone in all brain regions. The ability of PMA and mephedrone to increase 5-HT release was more prominent than PMMA and MDMA in striatum. The effect of PMA, mephedrone, and MDMA on 5-HT release was stronger than PMMA in the frontal cortex. PMA, PMMA and mephedrone were equally efficacious in nucleus accumbens, while MDMA produced a much stronger effect in this brain region. These data are in agreement with the studies of Matsumoto et al. (2014) who found that PMA, PMMA, and MDMA have a weaker effect on DA than that on 5-HT release.

Augmentation of DA and 5-HT release by new psychoactive drugs may be an indication of neurotoxicity observed after prolonged treatment-as evidenced in numerous studies for MDMA, the basic substance for development of new structural congeners (Capela et al. 2009; Molliver et al. 1990). However, there is only one study showing long-term (possibly neurotoxic) effects of high repeated doses ( $80 \mathrm{mg} / \mathrm{kg}$ for 4 days) of PMA and PMMA on serotonin neurons in hippocampus and frontal cortex (Steele et al. 1992). In another study, a 4-day administration of PMA at doses $10-20 \mathrm{mg} / \mathrm{kg}$ did not reduce cortical and hippocampal 5-HT content in spite of a decrease in 5-HIAA and SERT density (Callahan et al. 2006, 2007). Nevertheless, repeated treatment with new psychoactive drugs may cause disturbance in DA compartmentation by amphetamine derivatives which further leads to DA autooxidation and generation of oxidative stress (Barbosa et al. 2012; Halliwell 2006). Similarly, potent increase in 5-HT extracellular level may give rise to formation of dihydroxybitryptamine oxidative products such as tryptamine-4,5-diones (Ximenes et al. 2009). Those detrimental processes may cause retrograde degeneration of 5-HT terminals observed after long-term administration of psychostimulants (Granado et al. 2011). Moreover, potent increase in 5-HT extracellular level, particularly in frontal cortex, points to hallucinogenic properties of mephedrone and amphetamine derivatives as it was shown for mescaline (Aghajanian and Marek 1999; GonzálezMaeso and Sealfon 2009). The neurochemical basis of this effect is stimulation of 5-HT2A receptors situated in pyramidal cells in cortex and release of glutamate. In consequence, activation of NMDA and AMPA receptors leads to further stimulation of excitatory pathways projecting to VTA and nucleus raphe region and their activation. This mechanism seems to be responsible for hallucinogenic properties and abuse potential of cathinones and amphetamine derivatives (Capela et al. 2009; Creehan et al. 2015; Iversen et al. 2014; Nicholas 2004).

To summarize, the novel psychoactive drugs have the ability to markedly influence DA and 5-HT release in rat brain and to produce changes in monoamine synthesis and metabolism. Depending on the brain region, mephedrone, PMA, and PMMA show different pharmacological profiles and potency in their action. Observed changes in monoamine release and turnover suggest hallucinogenic, abuse, and neurotoxic risk of these drugs (See diagram below). Further studies with repeated treatment are necessary to understand the mechanism underlying the dopaminergic and serotoninergic neurotoxicity produced by those drugs.

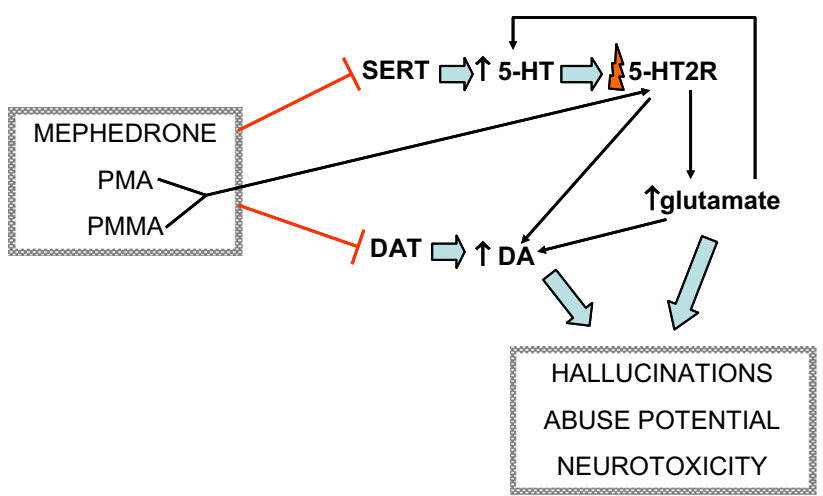


Diagram shows graphical presentation of mephedrone, PMA, and PMMA mechanism leading to hallucinogenic effects, abuse, and neurotoxicity.

Acknowledgments This study was supported by the Grant No 2013/09/B/NZ7/04104 from the National Science Center (Poland).

Open Access This article is distributed under the terms of the Creative Commons Attribution 4.0 International License (http://crea tivecommons.org/licenses/by/4.0/), which permits unrestricted use, distribution, and reproduction in any medium, provided you give appropriate credit to the original author(s) and the source, provide a link to the Creative Commons license, and indicate if changes were made.

\section{References}

Aghajanian GK, Marek GJ (1999) Serotonin and hallucinogens. Neuropsychopharmacol 21:16S-23S

Angoa-Pérez M, Kane MJ, Briggs DI, Francescutti DM, Sykes CE, Shah MM, Kuhn DM (2013) Mephedrone does not damage dopamine nerve endings of the striatum, but enhances the neurotoxicity of methamphetamine, amphetamine, and MDMA. J Neurochem 125:102-110

Bankson MG, Yamamoto BK (2004) Serotonin-GABA interactions modulate MDMA-induced mesolimbic dopamine release. J Neurochem 91:852-859

Barbosa DJ, Capela JP, Oliveira JM, Silva R, Ferreira LM, Siopa F, Carvalho F (2012) Pro-oxidant effects of Ecstasy and its metabolites in mouse brain synaptosomes. $\mathrm{Br} \mathrm{J}$ Pharmacol 165:1017-1033

Battaglia G, Yeh SY, O'Heam E, Molliver ME, Kuhar KJ, De Souza EB (1987) 3,4-Methylenedioxymethamphetamine and 3,4methylenedioxyamphetamine destroy serotonin terminals in rat brain: quantification of neurodegeneration by measurement of $\left[{ }^{3} \mathrm{H}\right]$-paroxetine-labelled serotonin uptake sites. J Pharmacol Exp Ther 242:911-916

Baumann MH, Ayestas MA, Partilla JS, Sink JR, Shulgin AT, Daley PF, Cozzi NV (2012) The Designer methcathinone analogs, mephedrone and methylone, are substrates for monoamine transporters in brain tissue. Neuropsychopharmacol 37:1192-1203

Caldicott DGE, Edwards NA, Kruys A, Kirkbride KP, Sims DN, Byard RW, Irvine RJ (2003) Dancing with "death": p-methoxyamphetamine overdose and its acute management. J Toxicol Clin Toxicol 41:143-154

Callaghan PD, Irvine RJ, Daws LC (2005) Differences in the in vivo dynamics of neurotransmitter release and serotonin uptake after acute para-methoxyamphetamine and 3,4-methylenedioxymethamphetamine revealed by chronoamperometry. Neurochem Int 47 : 350-361

Callaghan PD, Farrand K, Salem A, Hughes P, Daws LC, Irvine RJ (2006) Repeated administration of the substituted amphetamine p-methoxyamphetamine produces reductions in cortical 5-HT transporter binding but not 5-HT content, unlike 3,4-methylenedioxyamethamphetamine. Eur J Pharmacol 546:74-81

Callaghan PD, Owens WA, Javors MA, Sanchez TA, Jones DJ, Irvine RJ, Daws LC (2007) In vivo analysis of serotonin clearance in rat hippocampus revels that repeated administration of p-methoxyamphetamine (PMA), but not 3,4-methylenedioxymethamphetamine (MDMA), leads to long-lasting deficits in serotonin transporter function. J Neurochem 100:617-627
Capela JP, Carmo H, Remião F, Bastos ML, Meisel A, Carvalho F (2009) Molecular and cellular mechanisms of ecstasy-induced neurotoxicity: an overview. Mol Neurobiol 39:210-271

Colado MI, Camarero J, Mechać AO, Sanchez V, Esteban B, Elliot JM, Green AR (2001) A study of the mechanisms involved in the neurotoxic action of 3,4-methylenedioxymethamphetamine (MDMA, 'ecstasy') on dopamine neurons in mouse brain. Br J Pharmacol 134:1711-1723

Creehan KM, Vandewater SA, Taffe MA (2015) Intravenous selfadministration of mephedrone, methylone and MDMA in female rats. Neuropharmacol 92:90-97

Dal Cason TA (2001) A re-examination of the mono-methoxy positional ring isomers of amphetamine, methamphetamine and phenyl-2-propanone. Forensic Sci Int 119:168-194

Daws L, Irvine R, Callaghan P (2000) Differential behavioural and neurochemical effects of para-methoxyamphetamine and 3, 4-methylenedioxymethamphetamine in the rat. Prog NeuroPsychopharmacol Biol Psychiatr 24:955-977

Di Giovanni G, Di Matteo V, La Grutta V, Esposito E (2001) $\mathrm{m}$-Chlorophenylpiperazine excites non-dopaminergic neurons in the rat substantia nigra and ventral tegmental area by activating serotonin-2C receptors. Neuroscience 103:111-116

Di Matteo V, De Blasi A, Di Giulio C, Esposito E (2001) Role of 5-HT2C receptors in the control of central dopamine function. Trends Pharmacol Sci 22:229-232

Di Matteo V, Di Giovanni G, Pierucci M, Esposito E (2008) Serotonin control of central dopaminergic function: focus on in vivo microdialysis studies. Prog Brain Res 172:7-44

Dukat M, Young R, Glennon RA (2002) Effect of PMA optical isomers and 4-MTA in PMMA-trained rats. Pharmacol Biochem Behav 72:379-387

EMCDA (2014) European Drug Report: Trends and Developments, Lisbon, May, 2014

Felgate HE, Felgate PD, James RA, Sims DN, Vozzo DC (1998) Recent paramethoxyamphetamine deaths. J Anal Toxicol 22:169-172

Freezer A, Salem A, Irvine RJ (2005) Effects of 3,4-methylenedioxymethamphetamine (MDMA, "Ecstasy") and paramethoxyamphetamine on striatal 5-HT when co-administered with moclobemide. Brain Res 1041:48-55

Glennon R, Young R, Dukat M, Cheng Y (1997) Initial characterization of PMMA as a discriminative stimulus. Pharmacol Biochem Behav 57:151-158

Glennon R, Young R, Dukat M, Chang-Fong J, El-Zahabi M (2007) N-Methyl-1-(4-methoxyphenyl)-2-aminopropane (PMMA) and $\mathrm{N}$-methyl-1-(3,4-methylenedioxyphenyl)-2-aminopropane (MDMA) produce non-identical discriminative stimuli in rats. Pharmacol Biochem Behav 86:477-484

González-Maeso J, Sealfon SC (2009) Psychedelics and schizophrenia. Trends Neurosci 32:225-232

Gough B, Imam SZ, Blough B, Slikker W, Ali SF (2002) Comparative effects of substituted amphetamines (PMA, MDMA, and $\mathrm{METH})$ on monoamines in rat caudate. Ann N Y Acad Sci 96:410-420

Granado N, Ares-Santos S, Oliva I, O'Shea E, Martin ED, Colado MI, Moratalla R (2011) Dopamine D2-receptor knockout mice are protected against dopaminergic neurotoxicity induced by methamphetamine or MDMA. Neurobiol Dis 42:391-403

Green AR, Nutt DJ (2014) Pharmacology should be at the centre of all preclinical and clinical studies on new psychoactive substances (recreational drugs). J Psychopharmacol 28:711-718

Green AR, King MV, Shortall SE, Fone KCF (2014) The preclinical pharmacology of mephedrone; not just MDMA by another name. Br J Pharmacol 171:2251-2268 
Gudelsky GA, Yamamoto BK (2003) Neuropharmacology and neurotoxicity of 3,4-methylenedioxymethamphetamine. Methods Mol Med 79:55-73

Gudelsky GA, Yamamoto BK (2008) Actions of 3,4-methylenedioxymethamphetamine (MDMA) on cerebral dopaminergic, serotonergic and cholinergic neurons. Pharmacol Biochem Behav 90:198-207

Hadlock GC, Webb KM, McFadden LM, Chu PW, Ellis JD, Allen SC, Fleckenstein AE (2011) 4-Methylmethcathinone (mephedrone): neuropharmacological effects of a designer stimulant of abuse. J Pharmacol Exp Ther 339:530-536

Halliwell B (2006) Oxidative stress and neurodegeneration: where are we now? J Neurochem 97:1634-1658

Iversen L, White M, Treble R (2014) Designer psychostimulants: pharmacology and differences. Neuropharmacology 87:59-65

Johansen SS, Hansen AC, Müller IB, Lundemose JB, Franzmann MB (2003) Three fatal cases of PMA and PMMA poisoning in Denmark. J Anal Toxicol 27:253-256

Kehr J, Ichinose F, Yoshitake S, Goiny M, Sievertsson T, Nyberg F, Yoshitake T (2011) Mephedrone, compared with MDMA (ecstasy) and amphetamine, rapidly increases both dopamine and 5-HT levels in nucleus accumbens of awake rats. Br $\mathrm{J}$ Pharmacol 164:1949-1958

Lee AT, Vogt D, Rubinstein JL, Sohal VS (2014) A class of GABAergic neurons in the prefrontal cortex sends long-range projections to the nucleus accumbens and elicits acute avoidance behavior. J Neurosci 34:11519-11525

López-Arnau R, Martínez-Clemente J, Rodrigo T, Pubill D, Camarasa J, Escubedo E (2015) Neuronal changes and oxidative stress in adolescent rats after repeated exposure to mephedrone. Toxicol Appl Pharmacol 286:27-35

Lurie Y, Gopher A, Lavon O, Almog S, Sulimani L, Bentur Y (2012) Severe paramethoxymethamphetamine (PMMA) and paramethoxyamphetamine (PMA) outbreak in Israel. Clin Toxicol 50:39-43

Martínez-Clemente J, López-Arnau R, Abad S, Pubill D, Escubedo E, Camarasa J (2014) Dose and time-dependent selective neurotoxicity induced by mephedrone in mice. PLOS One 9:1-11

Matsumoto T, Maeno Y, Kato H, Seko-Nakamura Y, Monma-Ohtaki J, Ishiba A, Nagao M, Aoki Y (2014) 5-Hydroxytryptamine- and dopamine-releasing effects of ring-substituted amphetamines on rat brain: a comparative study using in vivo microdialysis. Eur Neuropsychopharmacol 24:1362-1370

McElrath K, O’Neill C (2011) Experiences with mephedrone pre-and post-legislative controls: perceptions of safety and sources of supply. Int J Drug Policy 22:120-127

Meyer MR, Wilhelm J, Peters FT, Maurer HH (2010) Beta-keto amphetamines: studies on the metabolism of the designer drug mephedrone and toxicological detection of mephedrone, butylone, and methylone in urine using gas chromatography-mass spectrometry. Anal Bioanal Chem 397:1225-1233

Molliver ME, Berger UV, Mamounas LA, Molliver DC, O'Hearn E, Wilson MA (1990) Neurotoxicity of MDMA and related compounds: anatomic studies. Ann N Y Acad Sci 600:649-664

Motbey CP, Clemens KJ, Apetz N, Winstock AR, Ramsey J, Li KM et al (2014) High levels of intravenous mephedrone (4-methylmethcathinone) self-administration in rats: neural concequences and comparison with methamphetamine. J Psychopharmacol $27: 823-836$
Nicholas DE (2004) Hallucinogens. Pharmacol Therapeutics 101:131-181

Paxinos G, Watson C (1998) The rat brain in stereotaxic coordinates. Academic Press, San Diego

Pifl C, Reither H, Hornykiewicz O (2015) The profile of mephedrone on human monoamine transporters differs from 3,4-methylenedioxymethamphetamine primarily by lower potency at the vesicular monoamine transporter. Eur J Pharmacol 755:119-126

Rickli A, Hoener MC, Liechti ME (2015) Monoamine transporter and receptor interaction profiles of novel psychoactive substances: para-halogenated amphetamines and pyrovalerone cathinones. Eur Neuropsychopharmaol 25:365-376

Rohanova M, Balikova M (2009) Studies on distribution and metabolism of para-methoxymethamphetamine (PMMA) in rats after subcutaneous administration. Toxicology 259:61-68

Rothman RB, Baumann MH (2003) Monoamine transporters and psychostimulant drugs. Eur J Pharmacol 479:23-40

Schifano F, Albanese A, Fergus S, Stair JL, Deluca P, Corazza O, Haugen LSY (2011) Mephedrone (4-methylmethcathinone; "Meow meow"): chemical, pharmacological and clinical issues. Psychopharmacology 214:593-602

Shortall SE, Spicer CH, Ebling FJP, Green AR, Fone KCF, King MV (2015) Contribution of serotonin and dopamine to changes in core body temperature and locomotor activity in rats following repeated administration of mephedrone. Addict Biol. doi:10. 1111/ADB. 12283

Simmler LD, Rickli A, Hoener MC, Liechti ME (2014) Monoamine transporter and receptor interaction profiles of a new series of designer cathinones. Neuropharmacol 79:152-160

Sprague JE, Nichols DE (1995) Inhibition of MAO-B protects against MDMA-induced neurotoxicity in the striatum. Psychopharmacology 118:357-359

Steele TD, Katz JL, Ricaurte GA (1992) Evaluation of the neurotoxicity of N-methyl-1-(4-methoxyphenyl)-2-aminopropane (paramethoxymethamphetamine, PMMA). Brain Res 589:349-352

Wood DM, Dargan PI (2012) Mephedrone (4-methylmethcathinone): what is new in our understanding of its use and toxicity. Prog Neuro-Psychopharmacol Biol Psychiatry 39:227-233

Wrona MZ, Dryhurst G (2001) A putative metabolite of serotonin, tryptamine-4,5-dione, is an irreversible inhibitor of tryptophan hydroxylase: possible relevance to the serotonergic neurotoxicity of methamphetamine. Chem Res Toxicol 14:1184-1192

Ximenes VF, Maghzal GJ, Turner R, Kato Y, Winterbourn CC, Kettle AJ (2009) Serotonin as a physiological substrate for myeloperoxidase and its superoxide-dependent oxidation to cytotoxic tryptamine-4,5-dione. Biochem J 425:285-293

Yamamoto BK, Nash JF, Gudelsky GA (1995) Modulation of methylenedioxymethamphetamine-induced striatal dopamine release by the interaction between serotonin and gammaaminobutyric acid in the substantia nigra. J Pharmacol Exp Ther 273:1063-1070

Young R, Dukat M, Malmusi L, Glennon RA (1999) Stimulus properties of PMMA: effect of optical isomers and conformational restriction. Pharmacol Biochem Behav 64:449-453

Zawilska JB (2014) Mephedrone and other cathinones. Curr Opin Psychiatry 27:256-262

Zawilska JB, Wojcieszak J (2013) Designer cathinones_an emerging class of novel recreational drugs. Forensic Sci Int 231:42-53 